\title{
FIELD STUDY ON HEAVY METAL REMOVAL IN A NATURAL WETLAND RECEIVING MUNICIPAL SEWAGE DISCHARGE
}

\author{
C. S. SHIBAMBU ${ }^{1}$, J. R. GUMBO ${ }^{1} \&$ W. M. GITARI ${ }^{2}$ \\ ${ }^{1}$ Department of Hydrology and Water Resources, University of Venda, South Africa. \\ ${ }^{2}$ Department of Ecology and Resources Management, University of Venda, South Africa.
}

\begin{abstract}
Constructed and natural wetlands have been used successfully in the treatment and polishing of municipal wastewater all over the world, including in South Africa. Here we report on the heavy metal removal in a natural wetland that is receiving municipal sewage discharge, Limpopo province, South Africa. The natural wetland is located downstream of Makhado oxidation ponds and is dominated by the reed plant Phragmites australis. The changes in the metal variation from discharge of oxidation ponds to middle section and downstream of the natural wetland was analysed for heavy metals by ICP-MS over a 12 month period. The annual rainfall data were obtained from Agricultural Research Council. The following heavy metals: total chromium, zinc, cadmium and lead were effectively reduced during the passage through the wetland, to levels below the Department of Water \& Sanitation (DWS) guidelines for waste water discharge. In contrast, the manganese and iron was reduced slightly above the DWS guideline value during the drier season and was higher during the wet season indicating a contribution of soil and water erosion. With copper it was effectively reduced during the wet and dry seasons with the exception in April, June and September when the downstream section was three times higher than the DWS guideline value. Thus the natural wetland was able to reduce considerable the heavy metals in the municipal discharge during its passage in the wetland. This is able to render the water in downstream of the wetland safe for rural communities to use the water for irrigation purposes.
\end{abstract}

Keywords: drinking water, heavy metal reduction, natural wetland, phragmites australis rural communities.

\section{INTRODUCTION}

Constructed and natural wetlands have been used successfully in the treatment and polishing of municipal wastewater all over the world, including in South Africa. In South Africa, freshwater resources are deteriorating due to the impacts of anthropogenic activities [1] and some of the country's water bodies are already hypertrophic [2]. From a South African perspective, nutrient rich materials in wastewater treatment works (WWTW) alone are in higher concentration than in nonpoint sources [3]. Oberholster et al. [3] indicate that in South Africa, only $7.4 \%$ of WWTW were awarded the green drop certification. About $92.6 \%$ of the South African WWTW may be said to be noncompliant and their continued operation raises the risks of eutrophication in South African freshwater resources. Oxidation ponds or stabilization ponds are an alternative wastewater treatment option that is practiced in South Africa to serve smaller towns and urban centres [4]. The oxidation ponds are cheaper to operate with low level skills but require more land, which is available in rural areas [5]. The use of oxidation ponds purifying domestic wastewater has achieved mixed success [5-8]. The oxidation 
ponds have been effective in reducing heavy metals in domestic wastewater before discharge to a water course [5]. The heavy metal removal efficiencies have been variable. For example the study of Butler et al. [5] showed the removal efficiency as follows: Iron (75\% to 98\%); cobalt (58\% to $60 \%$ ); lead ( $85 \%$ to $95 \%$ ); Zinc (74\% to $82 \%$ ); copper (39\%); nickel (16\%); chromium $(41 \%)$. Thus the release of these heavy metals to the water body may be detrimental to human health [9-11].

Thus to improve the quality of discharge effluent there is a need for wetlands (natural or constructed). The wetlands are located downstream of the oxidation ponds and habited by a variety of plants such as reeds and emergent hydrophytes [12]. The reed plant Phragmites australis has known to effectively remove and reduce heavy metals in wetlands according to Vymazal et al. [13]. There are several processes that are known to be taking place in wetlands environments and their role in reducing metal concentration and neutralizing the acidity of influent water have been examined. These processes include physical, chemical and biological processes [14]. This process involves the settling and sedimentation of particles and has been efficient in the removal of metals in water [15]. When heavy metals are in wetland environments, whether water is a flowing body or stagnant water body, they undergo a particular transformation [15]. There are a wide range of chemical processes that are involved in wetlands with regard to the removal of heavy metals and they are: adsorption, sorption and oxidation and hydrolysis of metals [15]. Biological removal is the most important process in wetlands and its most important pathway is by plants uptake [15]. There are a number of categories of plants found in wetland environments, which include emergent, surface floating, or free floating rooted leaves, sub-merged macrophytes and trees [15]. These plants use both leaves and roots to extract pollutants (as nutrients). Those with their roots systems submerged under water have the ability to extract their nutrients from sediments where metal atoms are captured.

The natural wetland is located downstream of Makhado oxidation ponds, Limpopo province of South Africa. In our study, the urban centre of Makhado township (Dzanani) has a population of 5673 in 2011 and the domestic sewage is discharged into Makhado oxidation ponds (http://census2011.adrianfrith.com/places/968027001). The wetland is dominated by the reed plant Phragmites australis. The main objective was to determine the levels of heavy metals in water as it flows downstream of the wetland.

\section{MATERIALS AND METHODS}

\subsection{The study area}

The three sampling points were selected (Fig. 1), effluent discharge (upstream) point (S22.89764; E30.04792), midstream point (S22.88833; E30.05620) and the downstream point (S22.88319; E30.06167). The water samples were monthly collected for a period of twelve months starting from November 2013 until October 2014. The downstream part of wetland is part of Mawoni River, a tributary of the Nzhelele River which is also a tributary of Limpopo River.

\subsection{Samples preparation and analysis}

The water samples were collected in to the $250 \mathrm{~mL}$ plastic bottles and stored in the cooler bag and be transported to the University of Venda laboratory. Once in the laboratory, the samples were filtered through Sartorius membrane filter nylon, $0.45 \mu \mathrm{m}$ (Germany) in a $20 \mathrm{~mL}$ centrifuge tube and acidified with a drop of dilute nitric acid. The samples were analysed for metals 


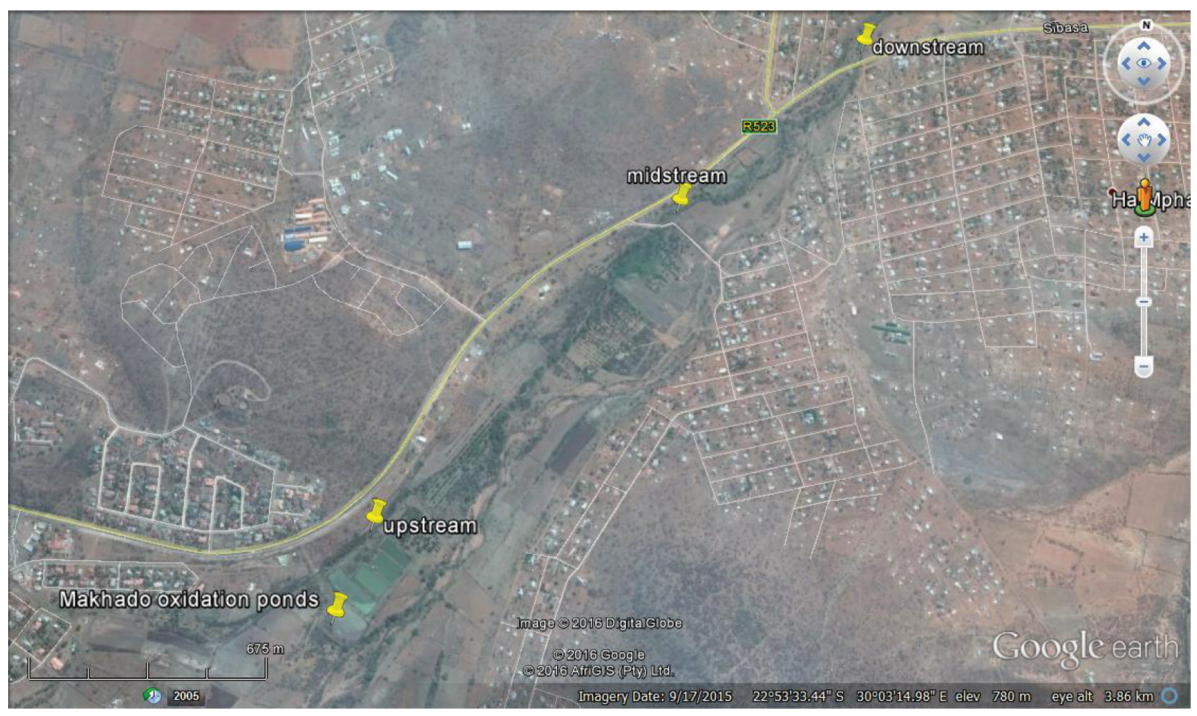

Figure 1: The location of Makhado oxidation ponds and the three sampling points and the tarred road (R523) (Google earth).

at Stellenbosch University in duplicate by ICP-MS (Agilent 7,700 instrument). The Agilent 7,700 instrument reported the trace element concentrations in parts per billion (ppb).

\subsection{Climate data}

The data (rainfall, air temperature and evapotranspiration) were obtained from the ARCInstitute of Soil, Climate and Water in Pretoria, South Africa. The data would assist in the interpretation of observed variables.

\subsection{Data analysis}

The graphs were drawn using Microsoft Excel 2010 and was used for correlation analysis of rainfall data and individual heavy metal content in different sections of the wetland was carried out and in calculating the percentage removal efficiency.

$\%$ Removal efficiency was calculated $=\left(1-\left(\frac{\text { downstream }}{\text { discharge }}\right)\right) * 100$

\section{RESULTS AND DISCUSSION}

There was variation in the levels of heavy metals, total chromium, zinc, cadmium, lead, manganese, iron and copper in different sections of the wetland (Figs. 2-8).

\subsection{Removal of total chromium}

The levels of total Cr were lower than the Department of Water Affairs guideline value of $50 \mathrm{ppb}$ for discharge of effluent to a water body (Fig. 2) and with the exception of May which was higher than the regulatory limit [18]. There was weak association $(-0.30)$ of rainfall events and 


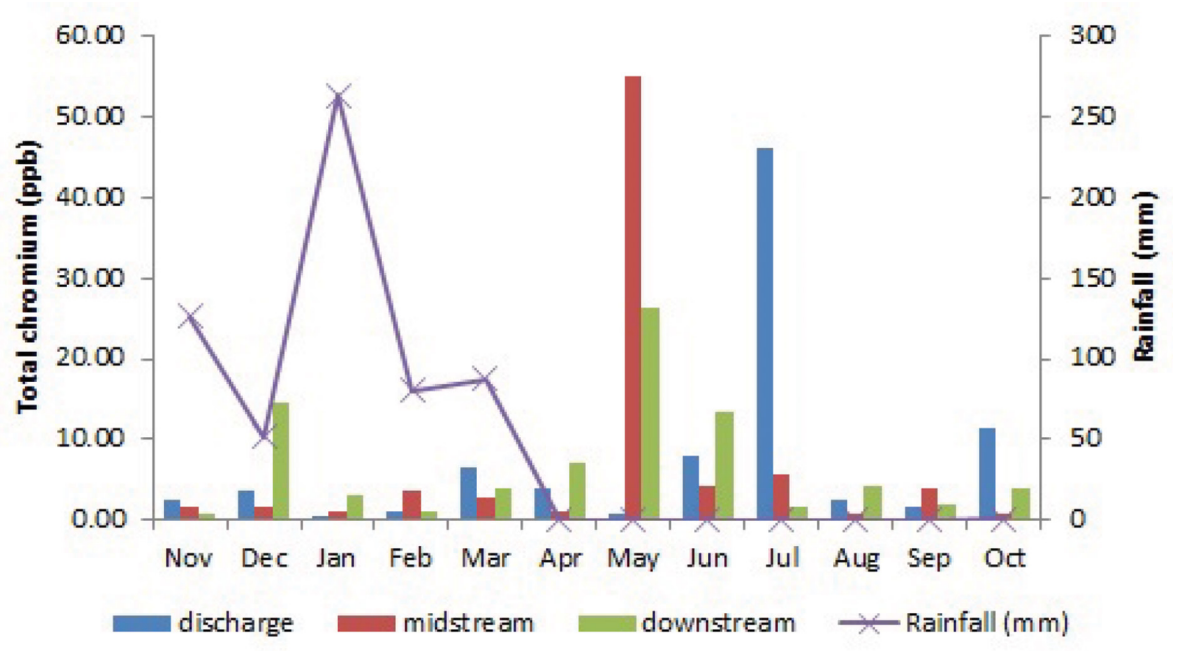

Figure 2: Variation in total chromium ( $\mathrm{ppb}$ ) concentration through the wetland.

levels of total $\mathrm{Cr}$ in the wetland. The removal efficiency was variable (-3,095\% to $96.2 \%)$ with the downstream sections having more total $\mathrm{Cr}$ than the upstream sections. Dense vegetation between the discharge and midstream point may have resulted to high plant uptake the metals may have been the cause for the reduction in total $\mathrm{Cr}$. The downstream section of the wetland has less vegetation and is transected by tarred road. Thus the factors may have contributed to higher levels of total $\mathrm{Cr}$ in downstream section. The study of Omprakash in Ethiopia showed that $54 \%$ of $\mathrm{Cr}$ was reduced in a constructed wetland [16]. Thus the wetland is able reduce the levels of $\mathrm{Cr}$ in different sections [17].

\subsection{Removal of zinc}

The levels of $\mathrm{Zn}$ were lower than the Department of Water Affairs guideline value of $300 \mathrm{ppb}$ for discharge of effluent to water body (Fig. 3; [18]). There was weak association $(-0.43)$ of rainfall events and levels of $\mathrm{Zn}$ in the wetland. The removal efficiency was variable $(-688.5 \%$ to $99.2 \%$ ) with the downstream sections. However, in February during the rainy season the wetland midsection had increasing $\mathrm{Zn}$ concentration than at the discharge point.

During April after the March rainfall the downstream point measured the highest concentration above both discharge and midstream point and at this point $\mathrm{Zn}$ concentrations were increased by more than $100 \%$ due to runoff transporting matter from the upstream to the downstream. Due to slow water flow in the wetland, $\mathrm{Zn}$ concentration remained increased by more than $100 \%$ in the following May and June months. However, these increased concentrations were followed by the highest reduction in July by $99.24 \%$. July was one of the dry months in the area and by this time runoff matter could have completely settled and allow for plant uptake. Zn removal by wetland can be removed by between 54\%-99\% [19].

\subsection{Removal of cadmium}

Cadmium measurements were in very low concentration in the wetland throughout the sampling period and always measured less than $0.30 \mathrm{ppb}$ (Fig. 4) and the levels conformed to the 


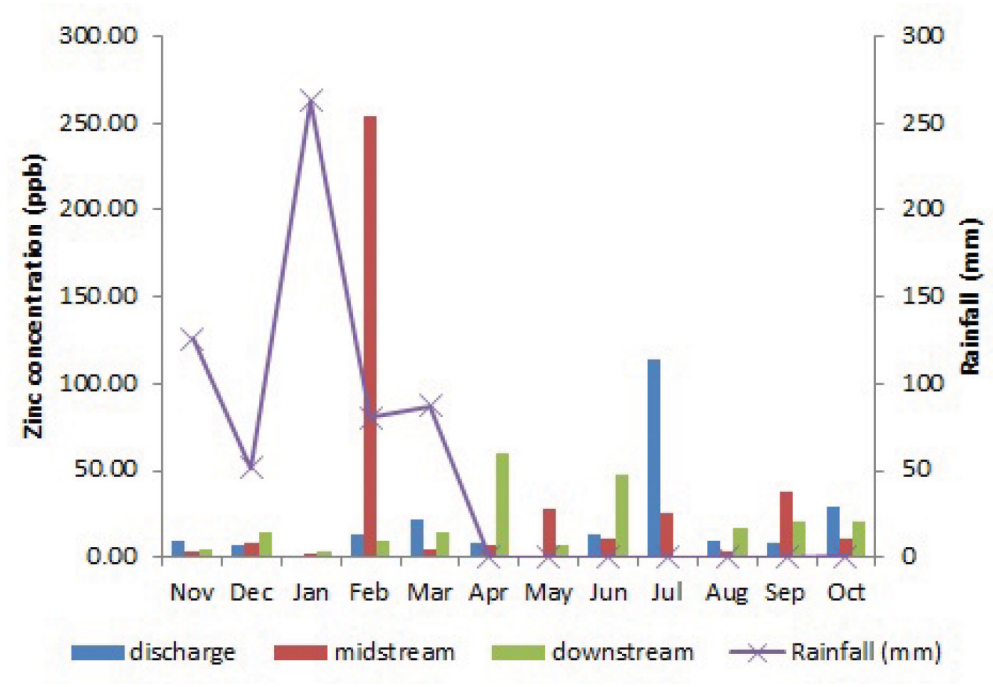

Figure 3: Variations in zinc (ppb) concentrations through the wetland.

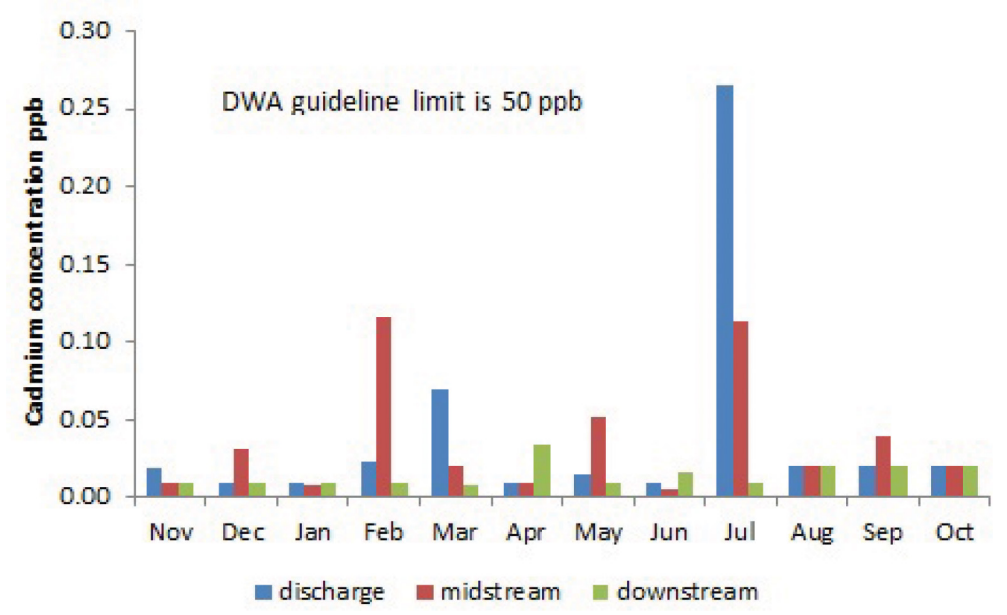

Figure 4: Variations in cadmium (ppb) concentrations through the wetland.

target water quality range for $50 \mathrm{ppb}$ in irrigation [18]. Although at low concentrations, it was neither reduced nor increased for a period of months of the sampling period. During March 2014 , Cd was reduced by $88.1 \%$ in the wetland. There was weak association $(-0.46)$ of rainfall events and levels of $\mathrm{Cd}$ in the wetland. However, this was followed by more than $100 \%$ increased concentrations during April 2014. March 2014 was a rainy season in the area and it is expected that the assimilative capacity of the wetland could have diluted the concentrations of Cd since it was always in very small concentrations. In April 2014 when runoff stopped it is expected that $\mathrm{Cd}$ may have settled down and dissolved in the wetland.

\subsection{Removal of lead}

Lead concentrations were generally low in the wetland with the highest measured at $5.77 \mathrm{ppb}$ in the midsections of the wetland during May 2014 with the lowest measured at $0.05 \mathrm{ppb}$ 
during February 2014 (Fig. 5) and did conform to the target water quality range set at $\leq 100$ $\mathrm{ppb}$ [18]. There was weak association $(-0.38)$ of rainfall events and levels of $\mathrm{Pb}$ in the wetland. During the rainfall season $\mathrm{Pb}$ was increased in the wetland by more than $100 \%$ and again in April 2014 immediately after rainfall season.

During rainy seasons it is expected that runoff could have eroded matter of different chemical composition and may have contributed to the increasing levels of $\mathrm{Pb}$. During dry seasons when runoff was off, the wetland, through its slow water movement, may have allowed for the dissolving of matter and hence the increase in $\mathrm{Pb}$ concentrations. In the same time plant uptake may have started to play in the wetland when sediments have settled down and allow reach by plants roots and there was a significant reduction in $\mathrm{Pb}$ concentration in the wetland at the end of the sampling period in October 2014. The efficiency of $\mathrm{Pb}$ removal from wetland can be between $95 \%$ and $99 \%$ and totally depend on its concentration and with little relation to its residence time [19].

\subsection{Removal of manganese}

Manganese levels in the wetland varied considerably with the discharge point recording the highest value at $2271.48 \mathrm{ppb}$ during December 2013, while the midstream recorded the lowest value at $0.39 \mathrm{ppb}$ during August 2014 (Fig. 6) and did not conform to the target water quality range for irrigation set at $100 \mathrm{ppb}$ [18]. There was strong association (0.85) of rainfall events and levels of $\mathrm{Pb}$ in the downstream section of the wetland. There were increases in the Mn concentration throughout the wetland and may be attributed rainfall events. The rainfall may have eroded soil material outside the wetland and then deposited this in the wetland thus contributing to high concentrations of $\mathrm{Mn}$ in the wetland.

However, during July, August and September of 2014 there were highest reductions of Mn through the wetland. During this period there was no rainfall recorded in the area so plant metal uptake may have been the source of metal reduction in the wetland.

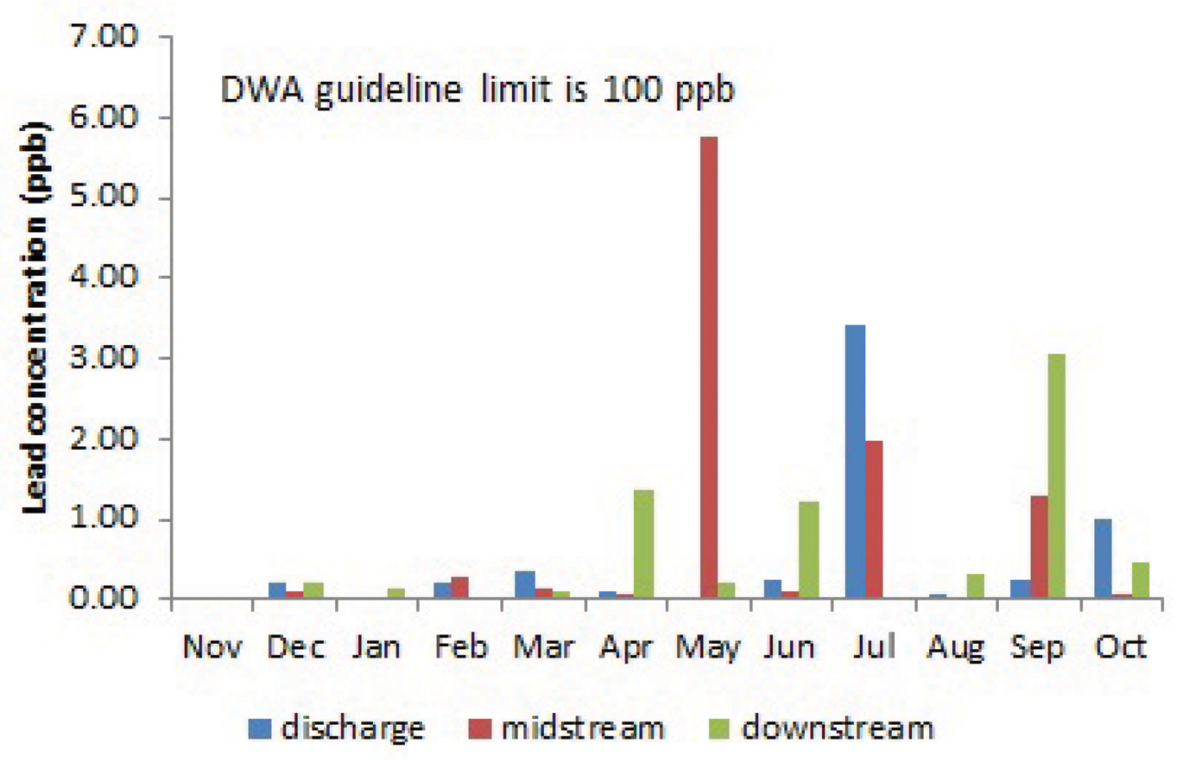

Figure 5: Variations in lead (ppb) concentrations through the wetland. 


\subsection{Removal of iron}

There were mostly high concentrations of Fe in the wetland (Fig. 7) and did not conform to the target water quality range for irrigation water set at $300 \mathrm{ppb}$ [18]. There was strong association (0.77) of rainfall events and levels of $\mathrm{Fe}$ in the downstream section of the wetland. During rainfall seasons Fe may have been introduced in the midsections of the wetland and given the fact that wetland are characterized by very slow movement of water Fe may have been given longer residence time in the wetland.

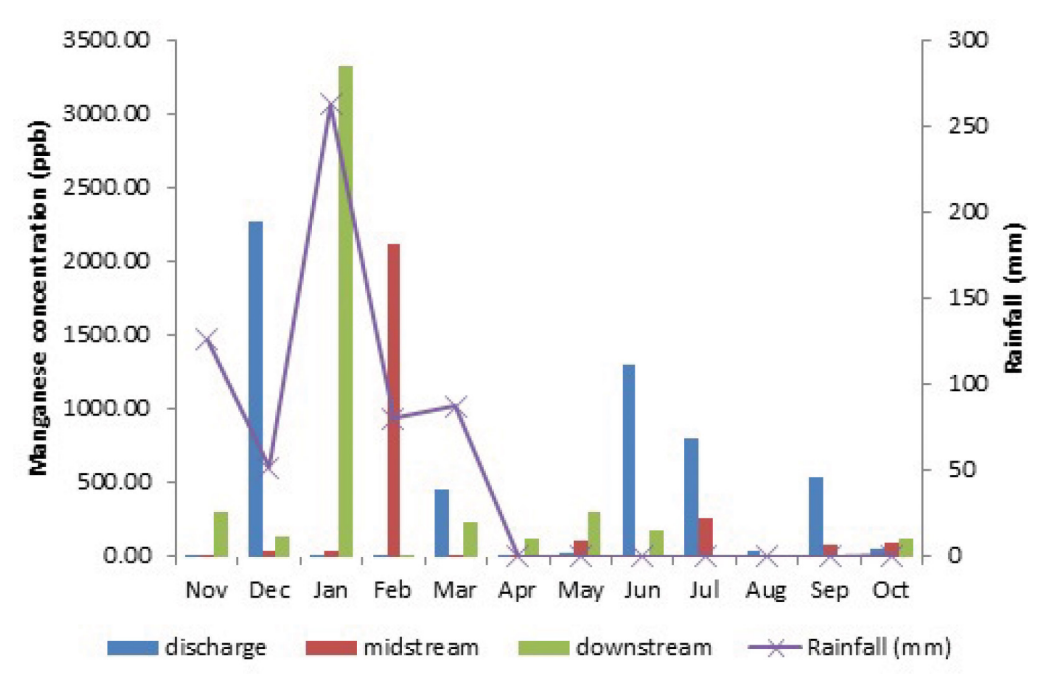

Figure 6: Variation in manganese (ppb) concentration through the wetland.

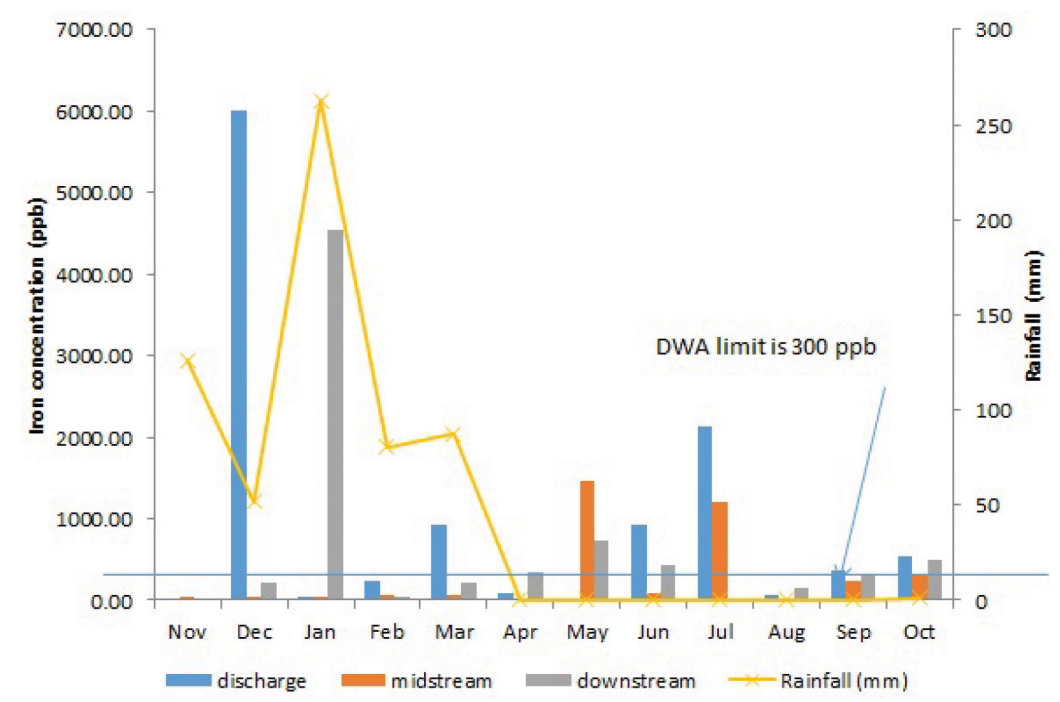

Figure 7: Variation in iron (ppb) concentration through the wetland. 


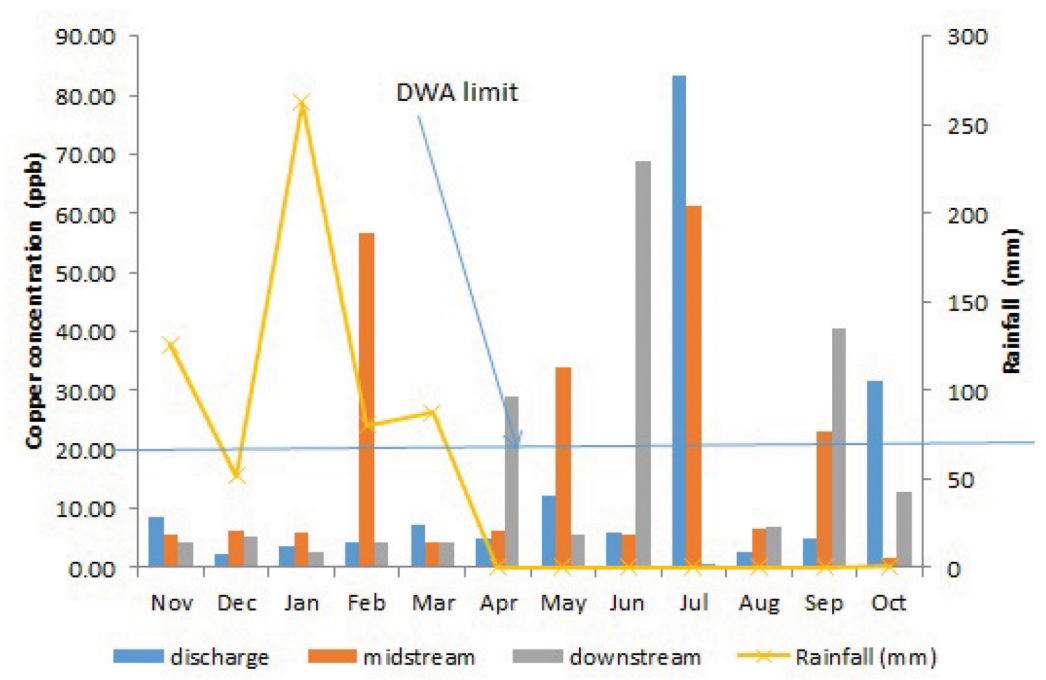

Figure 8: Variations in copper (ppb) concentrations through the wetland.

There was $96.48 \%$ reduction in Fe during December 2013. This significant reduction, however, was followed by increases of more than 100\% during January, April, May and August of 2014. Another significant reduction occurred at $99.58 \%$ in July 2014 though it was followed by more than 100\% increase during August 2014.

\subsection{Removal of copper}

Copper measurements reached the highest in July at the discharge point measuring $83.51 \mathrm{ppb}$ while the lowest measurements were at midstream point in October at $1.8 \mathrm{ppb}$ (Fig. 8). Cu concentrations did conform to the target water quality range in irrigation set at $20 \mathrm{ppb}$ [18]. There was weak association (-0.39) of rainfall events and levels of $\mathrm{Cu}$ in the wetland. During the twelve month sampling period $\mathrm{Cu}$ reduction in the wetland occurred in seven months and the highest reduction was in July by $99.39 \%$.

There were, however, increase in $\mathrm{Cu}$ concentrations in the wetland for five months of the sampling period. In December 2013 there was an increase in $\mathrm{Cu}$ concentration by more than $100 \%$. During this month the discharge point measured the lowest concentration of $\mathrm{Cu}$ but increased in the midsection and the downstream points. Runoff may have been the cause for the increase through erosional activities by introducing more matters in to wetland. During dry season in July in the area there was high reduction in $\mathrm{Cu}$ concentration and this could have been due to high plant uptake of metals. Cu can be removed by between $69 \%$ and $99 \%$ in wetlands [19]. The presence of excess levels of $\mathrm{Fe}, \mathrm{Zn}$ and $\mathrm{Cu}$ in the wetland may be attributed to use of iron, copper and brass scrubbers that are used during the cleaning of cooking utensils [11].

\section{CONCLUSIONS}

The slow flow of water through the wetland can be said to have a greater role in ensuring that the heavy metals have longer residence time in the wetland and provide time for the roots plants to absorb the metals. The heavy metals in the wetland did conform to the Department 
of Water and Sanitation guidelines with the exception of iron and manganese which increased during the rainy season.

\section{ACKNOWLEDGEMENT}

The University of Venda is acknowledged for their financial support for research study (S343). The climatic data was provided by the ARC-Institute of Soil, Climate and Water in Pretoria, South Africa.

\section{REFERENCES}

[1] Pindihama, G.K., Gumbo, J.R. \& Oberholster, P.J., Evaluation of a low cost technology to manage algal toxins in rural water supplies. African Journal of Biotechnology, 10(86), pp. 19883-19889, 2011. http://dx.doi.org/10.5897/AJBX11.024

[2] Harding, W.R., Thornton, J.A., Steyn, G., Panuska, J. \& Morrison, I.R., Hartbeespoort dam Remediation Project (Phase 1). Final Report (Volume 1). Project Number 58/2003. Completed October 2004. Department of Agriculture, Conservation, Environment and Tourism (DACET) of the Provincial Government of North West Province (NWPG), South Africa, p. 166, 2004.

[3] Oberholster, P.J., Botha, A.M., Chamier, J. \& de Klerk, A.R., Longitudinal trends in water chemistry and phytoplankton assemblage downstream of the riverview wwtp in the upper olifants river. Ecohydrology \& Hydrobiology, 13(1), pp. 41-51, 2013. http://dx.doi.org/10.1016/j.ecohyd.2013.03.001

[4] Jack, U., Mackintosh, G., Jagals, C. \& Van der Merwe, J., Development of a comprehensive monitoring and auditing tool for oxidation ponds systems in the middle vaal and upper orange catchment areas. Water SA, 32(5), pp. 655-660, 2006.

[5] Butler, E., Hung, Y.T., Al Ahmad, M.S., Yeh, R.Y.L., Liu, R.L.H. \& Fu, Y.P., Oxidation pond for municipal wastewater treatment. Applied Water Science, pp. 1-21, 2015.

[6] Meiring, P.G.J., Integrating oxidation ponds and biological trickling filters. Proceeding Third Biennial Conference, 1993.

[7] Pescod, M.B., The role and limitations of anaerobic pond systems. Water Science and Technology, 33(7), pp. 11-21, 1996. http://dx.doi.org/10.1016/0273-1223(96)00335-6

[8] van Niekerk, A., Seetal, A., Dama-Fakir, P., Boyd, L. \& Gaydon, P., Guideline document: package plants for the treatment of domestic wastewater. Pretoria, South Africa, pp.1-95, 2009.

[9] Ogunfowokan, A.O., Adenuga, A.A., Torto, N. \& Okoh, E.K., Heavy metals pollution in a sewage treatment oxidation pond and the receiving stream of the Obafemi Awolowo University, Ile Ife. Nigeria. Environmental Monitoring and Assessment, 143, pp. 25-41, 2008. http://dx.doi.org/10.1007/s10661-007-9945-2

[10] Baloyi, C., Gumbo, J.R. \& Muzerengi, C., Pollutants in sewage effluent and sludge and their impact on downstream water quality: a case study of Malamulele sewage plant, South Africa. Water Pollution XII, 182, p. 15, 2014.

[11] Kudakwashe K,. Shamuyarira, K.K., \& Gumbo, J.R., Assessment of heavy metals in municipal sewage sludge: a case study of limpopo province, South Africa. International Journal of Environmental Research and Public Health, 11(3), pp. 2569-2579, 2014. 
[12] Potgieter, M., The role of wetlands play in water reclamation: Science in Africa, www. sciencein Africa.co.za/2002/Januray/wetland.htm

[13] Vymazal, J., Švehla, J., Kröpfelová, L. \& Chrastný, V., Trace metals in phragmites australis and phalaris arundinacea growing in constructed and natural wetlands. Science of the Total Environment, 380(1), pp. 154-162, 2007. http://dx.doi.org/10.1016/j.scitotenv.2007.01.057

[14] Gazea, B. Adam, K. \& Kontopoulos, A., A Review of passive systems for the treatment of acid mine drainage. Mineral Engineering, 9(1), pp. 23-31, 1995. http://dx.doi.org/10.1016/0892-6875(95)00129-8

[15] http://dx.doi.org/10.1016/j.scitotenv.2007.01.057

[16] Sheoran, A.S. \& Sheoran, V., Heavy metal removal mechanism of acid mine drainage in wetlands: A critical review. Journal of Minerals Engineering, 19(2), pp. 105-116, 2006.

http://dx.doi.org/10.1016/j.mineng.2005.08.006

[17] Omprakash, S., Reduction of heavy metals from waste water by Wetland. International Letters of Natural Sciences, 7, pp. 35-43, 2014.

[18] Matagi, S.V., Swai, D. \& Mugabe., R., A review of heavy metal removal mechanisms in wetlands. African Journal of Tropical Hydrobiology and Fisheries, 8(1), pp. 13-25, 1998. http://dx.doi.org/10.4314/ajthf.v8i1.1386

[19] Department of Water Affairs (DWA), Annexure: General and Special Effluent Standards, Government Gazette 18 May 1984 no 9225. Regulation no. 99118 May 1984.

[20] Chen, M., Tang, Y., Li, X. \& Yu, Z., Study on heavy metal removal efficiencies of constructed wetlands with different substrates. Journal of Water Resource and Protection, 1(1), pp. 22-34, 2009. http://dx.doi.org/10.4236/jwarp.2009.11004 